
\title{
28 Research Square \\ Factors Related to ICU-Acquired Infections Incidence in Iran: Analysis of National Nosocomial Infections Registry Data
}

Neda Izadi

Shahid Beheshti University of Medical Sciences School of Public Health and Safety

Babak Eshrati

Iran University of Medical Sciences

Yadollah Mehrabi

Shahid Beheshti University of Medical Sciences School of Public Health and Safety

Korosh Etemad

Shahid Beheshti University of Medical Sciences School of Public Health and Safety

Seyed-Saeed Hashemi-Nazari ( $\nabla$ nedaizadi2255@gmail.com )

Shahid Beheshti University of Medical Sciences School of Public Health and Safety

Research

Keywords: Factors, Infection, Incidence, Intensive Care Units, Iran

Posted Date: October 7th, 2020

DOI: https://doi.org/10.21203/rs.3.rs-86026/v1

License: (c) (i) This work is licensed under a Creative Commons Attribution 4.0 International License.

Read Full License 


\section{Abstract}

Background: Patients admitted to intensive care units (ICUs) are particularly susceptible to hospitalacquired infections (HAls) and the HAls are higher in the ICUs than other wards of the hospital. This study aimed at investigating factors associated with ICU-acquired infections incidence in Iran.

Methods: In this multi-center study, Iranian nosocomial infections surveillance (INIS) and hospital statistics and information system (AVAB) were used to collect data on patients with HAls in 2018. The data was expanded based on 12 months of the year (13,632 records in terms of "hospital-ward-month") and then, the last observation carried forward method was used to replace the missing data. The generalized negative binomial regression with "patient-days" as an offset variable was used to identify the factors affecting ICU-acquired infections incidence.

Results: The median age of patients was 57.5 (IQR=55.09) years. Of the $22.92 \%, 5.76 \%, 13.62 \%, 43.41 \%$, and $14.29 \%$ of patients were in NICU, PICU, internal ICU, general ICU, and surgical ICU, respectively. Only $13.73 \%$ of hospitals were in efficient zone (zone III). Based on multivariable regression, the number of death (IRR=1.02), the number of infections due to the device (catheters and ventilators) (IRR=1.1), ward type (PICU (IRR=1.58), internal ICU (IRR=1.63), general ICU (IRR=1.53) and surgical ICU (IRR=1.47)), hospital's expertise, hospital's accreditation, bed occupancy rate indicator (IRR=1.17 for moderate conditions) were associated with an increase of ICU-acquired infections incidence. Infection due to ventilator, infection due to catheter, and the number of surgery in hospitals reduced $5 \%, 7 \%$, and $1 \%$ incidence of infections, respectively.

Conclusions: Based on the results, the most common ICU-acquired infections were VAE and UTI. Therefore due to the high sensitivity of intensive care units, full hygiene should be taught to the medical staff, especially the ICU wards. Ventilators and catheters should be used in special circumstances and minimum duration.

\section{Background}

Hospital-acquired infections (HAls) are a major health concern worldwide and are regarded as the most common complications in any health-care facility [1]. According to the European Center for Disease Prevention and Control estimates, more than 2.5 million cases of HAls occur annually in Europe and the United States, HAls account for 100,000 deaths annually [2].

Patients admitted to intensive care units (ICUs) are particularly susceptible to HAls and the morbidity of HAls is higher in the ICUs than other wards of the hospital, which are often severe [2,3]. ICU-acquired infections affect patient's safety in developing and developed countries and are considered responsible for a substantial proportion of disability, increased length of stay (LOS) and mortality, delays in the recovery process, and impose additional costs and financial burden on the healthcare system of countries $[4,5]$. 
Studies on infection in intensive care in Europe demonstrated the prevalence of ICU-acquired infections to be significantly higher (20.6\%) [6]. The important ICU-acquired infections are ventilator-associated pneumonia (VAP), urinary catheter-related infection (UTI), central line-associated bloodstream infection (CLABSI), and surgical site infection (SSI) [6, 7]. In addition, a meta-analysis study by Ling et al. in Southeast Asia showed that the pooled incidence of HAI was 20 patient per $1000 \mathrm{ICU}$-days [8].

The majority of these infections are associated with the aging, severity of the disease, and healthcare factors including increase the use of invasive devices (endotracheal tubes, tracheostomy, central venous and urinary catheterization, and mechanical ventilation), type of providing health services, and inappropriate use of antimicrobial drugs $[6,7,9]$.

Hence, HAls prevention is now the most successful intervention and the recognition of the magnitude of related factors to the incidence of ICU-acquired infections has become essential for adopting proper infection control measures and reducing the incidence of infection in hospitals especially in ICU wards. Therefore, this study aimed at investigating factors associated with ICU-acquired infections incidence in Iran.

\section{Methods}

\section{Data sources}

In this multi-center study, Iranian nosocomial infections surveillance (INIS) and hospital statistics and information system (AVAB) were used to collect data on patients with HAls from 662 hospitals in 2018. The national infectious control committee registers the HAls including the following: bone and joint, central nervous system, chorionic villus sampling, eye, ear, nose, throat or mouth, urinary tract infections, ventilator-associated events, surgical site infections, central line-associated bloodstream infections, gastrointestinal system, reproductive tract infection, and skin and soft tissue infections. The data is collected to reduce mortality, morbidity, and complications of HAls.

Iranian nosocomial infections surveillance collects data from about 863 hospitals and records different types of information in different units of each hospital including age, gender, type of HAls, number of hospitalizations, patient-day, number of deaths, number of surgeries, date of infection, province, university, affiliated organization, devices used, and outcome of infection. In addition, we extracted performance indicators including the average LOS, occupancy rate, and bed turnover from AVAB that is a web-based system for each hospital.

\section{Expanded data and missing data imputation}

The data including 12,586 records in terms of "hospital-ward-month" for ICU-acquired infections was expanded based on 12 months of the year (13,632 records in terms of "hospital-ward-month") and then, the last observation carried forward (LOCF) method was used to replace the missing data. In LOCF 
imputation, first, the data on each variable in each hospital ward was sorted in terms of months, and the last observation was replaced through the forward method; then, the data on the same variable was sorted in terms of the reversed order of months and the last observation was replaced for the missing values through the backward method. Finally, the average values obtained in the two steps of forward and backward methods were used as the value of the missing data. In addition, the hospitals with no data on the number of infections and hospitalizations (in none of the months under the study) were excluded. Final ICU-acquired infections were 10,836 records obtained from 579 hospitals.

\section{National standard for hospital performance indicators}

Hospital performance indicators were categorized on the basis of the standards of Ministry of Health and Medical Education (MOHME) of Iran as follows:

Average LOS (day): $<3.5$ (desirable), 3.5-4 (moderate) and $>4$ (undesirable)

Bed occupancy rate (\%): >70 (desirable), 60-70 (moderate) and $<60$ (undesirable)

Bed turnover rate: >24 (desirable), 17-24 (moderate) and < 17 (undesirable)

Death to bedridden ratio (\%): $<2$ (desirable), $2-3$ (moderate) and $>3$ (undesirable)

In addition, the national average rate of bed turnover (134.24) and bed occupancy (62.73) was used to plot the Pabon Lasso graphical chart. The plotted Pabon Lasso graph indicates four zones, where zone I is the inefficient area, zone II, zone III are the efficient area of the model, and zone IV.

\section{Data Analysis}

Mean (standard deviation), median (interquartile range) and count (percentage) were used to describe quantitative and qualitative variables, respectively.

To identify the factors affecting ICU-acquired infections incidence, we used generalized negative binomial regression with "patient-days" as an offset variable. All the variables with a p-value of less than 0.2 at the univariable model entered into the multivariable regression model. Data were analyzed by the Stata (version 12 ) and $p<0.05$ was considered statistically significant for all statistical tests.

\section{Results}

The median age of patients was $57.5(\mathrm{IQR}=55.09)$ years. The median hospitalization-infection length and hospital LOS in the patients were $8.28(\mathrm{IQR}=12.8)$ days and $21(\mathrm{IQR}=21.75)$ days, respectively. The highest median of the number of death was observed in internal ICU $(7, I Q R=10)$. The distribution of different variables by type of ICU in Iran hospitals was shown in Table 1. 
Table 1

Distribution of different variables by type of ICU in Iran hospitals-2018

\begin{tabular}{|c|c|c|c|c|c|c|c|}
\hline Variable & $\begin{array}{l}\text { Hospitalization- } \\
\text { infection length } \\
\text { (day) }\end{array}$ & $\begin{array}{l}\text { Hospital } \\
\text { LOS } \\
\text { (day) }\end{array}$ & $\begin{array}{l}\text { Mean } \\
\text { age }\end{array}$ & $\begin{array}{l}\text { Bed } \\
\text { occupancy } \\
\text { rate }\end{array}$ & $\begin{array}{l}\text { Bed } \\
\text { turnover } \\
\text { rate }\end{array}$ & $\begin{array}{l}\text { Number } \\
\text { of } \\
\text { death }\end{array}$ & $\begin{array}{l}\text { Number } \\
\text { of } \\
\text { surgery }\end{array}$ \\
\hline \multicolumn{8}{|l|}{ NICU } \\
\hline $\mathbf{N}$ & 2484 & 2172 & 2484 & 2388 & 2388 & 2484 & 2484 \\
\hline Mean & 10.55 & 21.83 & 15.44 & 69.59 & 171.05 & 12.03 & 1.98 \\
\hline (SD) & 22.8 & 24 & 33.69 & 12.07 & 911.05 & 452.16 & 15.58 \\
\hline Median & 6 & 17 & 0 & 70.9 & 98.63 & 1 & 0 \\
\hline (IQR) & 10 & 19.66 & 1 & 16.52 & 41.33 & 4 & 0 \\
\hline \multicolumn{8}{|l|}{ PICU } \\
\hline $\mathbf{N}$ & 624 & 576 & 624 & 600 & 600 & 624 & 624 \\
\hline Mean & 14.22 & 27.94 & 19.27 & 74.8 & 90.25 & 4.18 & 5.72 \\
\hline (SD) & 17.1 & 24.76 & 28.97 & 10.68 & 25.63 & 4.18 & 14.82 \\
\hline Median & 10 & 21.16 & 5 & 76.41 & 83.99 & 3 & 0 \\
\hline (IQR) & 14 & 21.5 & 14.61 & 13.07 & 27.38 & 5 & 4 \\
\hline \multicolumn{8}{|c|}{ Internal ICU } \\
\hline $\mathbf{N}$ & 1476 & 1344 & 1476 & 1452 & 1452 & 1476 & 1476 \\
\hline Mean & 13.33 & 29.96 & 61.68 & 70.98 & 88.52 & 9.36 & 8.22 \\
\hline (SD) & 13.23 & 27.97 & 18.04 & 13.95 & 32.39 & 8.89 & 28.3 \\
\hline Median & 10.33 & 25 & 65.6 & 73.1 & 82.45 & 7 & 0 \\
\hline (IQR) & 13.5 & 22.2 & 18.25 & 17.44 & 29.8 & 10 & 6 \\
\hline \multicolumn{8}{|c|}{ General ICU } \\
\hline $\mathbf{N}$ & 4704 & 4368 & 4704 & 4584 & 4584 & 4704 & 4704 \\
\hline Mean & 14.13 & 26.67 & 60.7 & 65.15 & 147.71 & 7.97 & 12.41 \\
\hline (SD) & 25.17 & 29.52 & 18.99 & 16.12 & 736.67 & 7.74 & 33.29 \\
\hline Median & 8.25 & 20.57 & 65.21 & 66.83 & 92.56 & 6 & 1 \\
\hline (IQR) & 13.03 & 21.5 & 23.98 & 21.23 & 40.07 & 8 & 11 \\
\hline \multicolumn{8}{|c|}{ Surgical ICU } \\
\hline $\mathbf{N}$ & 1548 & 1416 & 1548 & 1524 & 1524 & 1548 & 1548 \\
\hline
\end{tabular}




\begin{tabular}{|llllllll|} 
Mean & 13.78 & 29.26 & 55.78 & 71.33 & 182.31 & 5.62 & 38.86 \\
(SD) & 15.33 & 23.06 & 17.5 & 11 & 988.42 & 6.1 & 84.34 \\
\hline Median & 10.28 & 25.12 & 59.28 & 71.74 & 92.11 & 4 & 18 \\
(IQR) & 12.25 & 22.65 & 22.36 & 16.08 & 36.11 & 7 & 53 \\
\hline Total & & & & & & & \\
\hline N & 10836 & 9876 & 10836 & 10548 & 10548 & 10836 & 10836 \\
\hline Mean & 13.15 & 26.5 & 47.37 & 68.4 & 146.58 & 8.54 & 12.84 \\
(SD) & 21.69 & 27.17 & 30.78 & 14.35 & 752.26 & 216.56 & 42.47 \\
\hline Median & 8.28 & 21 & 57.5 & 69.97 & 91.75 & 4 & 0 \\
(IQR) & 12.8 & 21.75 & 55.09 & 18.26 & 38.3 & 8 & 9 \\
\hline
\end{tabular}

Of the $22.92 \%, 5.76 \%, 13.62 \%, 43.41 \%$, and $14.29 \%$ of patients were in NICU, PICU, internal ICU, general ICU, and surgical ICU, respectively. Concerning patient-days, the rate of ICU-acquired infections was 24.6, $21.3,20.9,10.1$, and 7.6 per 1,000 patient-days for internal ICU, general ICU, surgical ICU, PICU, and NICU, respectively. The most common ICU-Als were VAE (6.49 per 1,000 patient-days) and UTI (3.32 per 1,000 patient-days). Based on hospital expertise and hospital type $90.53 \%$ and $63.87 \%$ of hospitals were general hospitals and medium hospitals (bed size $=100-320$ ). In addition, based on the Pabon Lasso model, only $13.73 \%$ of hospitals were in efficient zone (zone III) (Table 2). Considering performance indicators including average LOS, bed occupancy and bed turnover, the frequency of desirable conditions was higher in hospitals (Fig. 1). 
Table 2

The frequency of hospital variables in ICU of Iran hospitals-2018

\begin{tabular}{|c|c|c|c|}
\hline Variables & & $\mathbf{N}$ & $\%$ \\
\hline \multirow[t]{6}{*}{ Ward type } & NICU & 2484 & 22.92 \\
\hline & PICU & 624 & 5.76 \\
\hline & Internal ICU & 1476 & 13.62 \\
\hline & General ICU & 4704 & 43.41 \\
\hline & Surgical ICU & 1548 & 14.29 \\
\hline & Total & 10836 & 100 \\
\hline \multirow[t]{4}{*}{ Hospital type } & Educational-therapy & 3168 & 31.92 \\
\hline & Therapy & 6132 & 61.79 \\
\hline & Educational-therapy- research & 624 & 6.29 \\
\hline & Total & 9924 & 100 \\
\hline \multirow[t]{10}{*}{ Hospital expertise } & General & 8952 & 90.53 \\
\hline & Pediatrics & 300 & 3.03 \\
\hline & Gynecology & 276 & 2.79 \\
\hline & Psychiatric & 36 & 0.36 \\
\hline & Accident & 48 & 0.49 \\
\hline & Heart & 156 & 1.58 \\
\hline & Ortopedi & 24 & 0.24 \\
\hline & Cancer & 84 & 0.85 \\
\hline & Surgery & 12 & 0.12 \\
\hline & Total & 9888 & 100 \\
\hline \multirow[t]{4}{*}{ Accreditation } & Excellent & 456 & 4.61 \\
\hline & 1 & 8628 & 87.26 \\
\hline & 2 & 804 & 8.13 \\
\hline & Total & 9888 & 100 \\
\hline \multirow[t]{3}{*}{ Affiliation } & Government & 7572 & 71.46 \\
\hline & Semi- government & 528 & 4.98 \\
\hline & Profit & 1992 & 18.8 \\
\hline
\end{tabular}




\begin{tabular}{|c|c|c|c|}
\hline \multicolumn{2}{|l|}{ Variables } & \multirow{2}{*}{$\begin{array}{l}\mathbf{N} \\
504\end{array}$} & \multirow{2}{*}{$\begin{array}{l}\% \\
4.76\end{array}$} \\
\hline & Non-Profit/other & & \\
\hline & Total & 10596 & 100 \\
\hline \multirow[t]{6}{*}{ Hospital based on bed size } & Small (< 100 bed) & 1860 & 17.55 \\
\hline & Medium (100-320) & 6768 & 63.87 \\
\hline & Large (320-600) & 1464 & 13.82 \\
\hline & X.Large $(600-1000)$ & 456 & 4.3 \\
\hline & Hospital complex $(>1000)$ & 48 & 0.45 \\
\hline & Total & 10596 & 100 \\
\hline \multirow[t]{5}{*}{ Pabon Lasso } & Zone I (not efficient) & 2964 & 27.35 \\
\hline & Zone II & 276 & 2.55 \\
\hline & Zone III (efficient) & 1788 & 13.73 \\
\hline & Zone IV & 6108 & 56.37 \\
\hline & Total & 10836 & 100 \\
\hline
\end{tabular}

\section{The risk of ICU-acquired infections incidence}

In investigating the relationship between ICU-acquired infections incidence and hospital variables and indicators, the number of death (death in HAls patients) was associated with an increase of ICU-acquired infections incidence (IRR $=1.02 ; 95 \% \mathrm{Cl}: 1.01-1.02)$. Based on multivariable generalized negative binomial regression, the number of infections due to the device (catheters and ventilators) was associated with a $10 \%$ increase in ICU-acquired infections incidence rate (IRR $=1.1 ; 95 \% \mathrm{Cl}: 1.08-1.13$ ). Also, PICU, internal ICU, general ICU, and surgical ICU were associated with a $58 \%, 63 \%, 53 \%$, and $47 \%$ increase in ICU-acquired infections incidence rate compared to the NICU, respectively. Considering the hospital's expertise, the largest increase in the incidence of ICU-acquired infections was related to the heart hospitals (IRR $=2.91 ; 95 \% \mathrm{Cl}: 2.37-3.57)$, accidents (IRR $=2.08 ; 95 \% \mathrm{Cl}: 1.6-2.71)$, and pediatric hospitals (IRR $=1.95 ; 95 \% \mathrm{Cl}: 1.67-2.27)$. In addition, the risk of an increase in the incidence of the ICUacquired infections was $23 \%$ (IRR $=1.23 ; 95 \% \mathrm{Cl}: 1.12-1.35)$ and $73 \%(\mathrm{IRR}=1.73 ; 95 \% \mathrm{Cl}: 1.52-1.97)$ higher in hospitals with accreditation 1 and 2, respectively. In hospitals with moderate conditions in terms of bed occupancy rate indicator, the incidence of ICU-acquired infections was 1.17 times higher than the desirable conditions (IRR $=1.17 ; 95 \% \mathrm{Cl}$ : 1.09-1.25) (Table 3). 
Table 3

The univariable and multivariable generalized negative binomial regression between ICU-acquired infections incidence and hospital variables and indicators in Iran hospitals

\begin{tabular}{|c|c|c|c|c|c|c|}
\hline \multirow[t]{2}{*}{ Variables } & \multicolumn{3}{|c|}{ Univariable } & \multicolumn{3}{|c|}{ Multivariable } \\
\hline & IRR & $95 \% \mathrm{Cl}$ & $\begin{array}{l}\text { P- } \\
\text { Value }\end{array}$ & IRR & $95 \% \mathrm{Cl}$ & $\begin{array}{l}\text { P- } \\
\text { Value }\end{array}$ \\
\hline \multicolumn{7}{|l|}{ Ward type } \\
\hline NICU & 1 & - & - & 1 & - & - \\
\hline PICU & 1.88 & $1.72-2.05$ & $\begin{array}{l}<.001 \\
0\end{array}$ & 1.58 & $\begin{array}{l}1.42- \\
1.78\end{array}$ & $\begin{array}{l}< \\
0.001\end{array}$ \\
\hline Internal ICU & 2.47 & $2.33-2.62$ & $\begin{array}{l}< \\
0.001\end{array}$ & 1.63 & $\begin{array}{l}1.49- \\
1.79\end{array}$ & $\begin{array}{l}< \\
0.001\end{array}$ \\
\hline General ICU & 2.33 & $2.22-2.44$ & $\begin{array}{l}< \\
0.001\end{array}$ & 1.53 & $\begin{array}{l}1.41- \\
1.66\end{array}$ & $\begin{array}{l}< \\
0.001\end{array}$ \\
\hline Surgical ICU & 2.03 & $1.91-2.15$ & $<001$ & 1.47 & $1.34-1.6$ & $\begin{array}{l}< \\
0.001\end{array}$ \\
\hline \multicolumn{7}{|l|}{ Hospital type } \\
\hline Educational-therapy & 1.03 & $0.99-1.07$ & 0.14 & 1.06 & $\begin{array}{l}1.007- \\
1.13\end{array}$ & 0.02 \\
\hline Therapy & 1 & - & - & 1 & - & - \\
\hline Educational-therapy- research & 1.15 & $1.07-1.24$ & $<.001$ & 1.06 & $\begin{array}{l}0.96- \\
1.16\end{array}$ & 0.2 \\
\hline \multicolumn{7}{|l|}{ Hospital expertise } \\
\hline General & 2.5 & $2.22-2.8$ & $\begin{array}{l}< \\
0.001\end{array}$ & 1.82 & $1.6-2.07$ & $\begin{array}{l}< \\
0.001\end{array}$ \\
\hline Pediatrics & 1.7 & $1.46-1.98$ & $\begin{array}{l}<.001 \\
0.001\end{array}$ & 1.95 & $\begin{array}{l}1.67- \\
2.27\end{array}$ & $\begin{array}{l}<.001 \\
0.001\end{array}$ \\
\hline Gynecology & 1 & - & - & 1 & - & - \\
\hline Psychiatric & 1.8 & $1.26-2.59$ & 0.001 & 1.88 & $\begin{array}{l}0.72- \\
4.88\end{array}$ & 0.19 \\
\hline Accident & 2.78 & $2.11-3.65$ & $\begin{array}{l}< \\
0.001\end{array}$ & 2.08 & $1.6-2.71$ & $\begin{array}{l}< \\
0.001\end{array}$ \\
\hline Heart & 7.24 & $5.99-8.75$ & $\begin{array}{l}<.001 \\
0\end{array}$ & 2.91 & $\begin{array}{l}2.37- \\
3.57\end{array}$ & $\begin{array}{l}< \\
0.001\end{array}$ \\
\hline Ortopedi & 1.54 & $0.95-2.5$ & 0.07 & 0.71 & $0.42-1.2$ & 0.2 \\
\hline
\end{tabular}

IRR = Incidence Rate Ratio; $\mathbf{C l}=$ Confidence Interval 


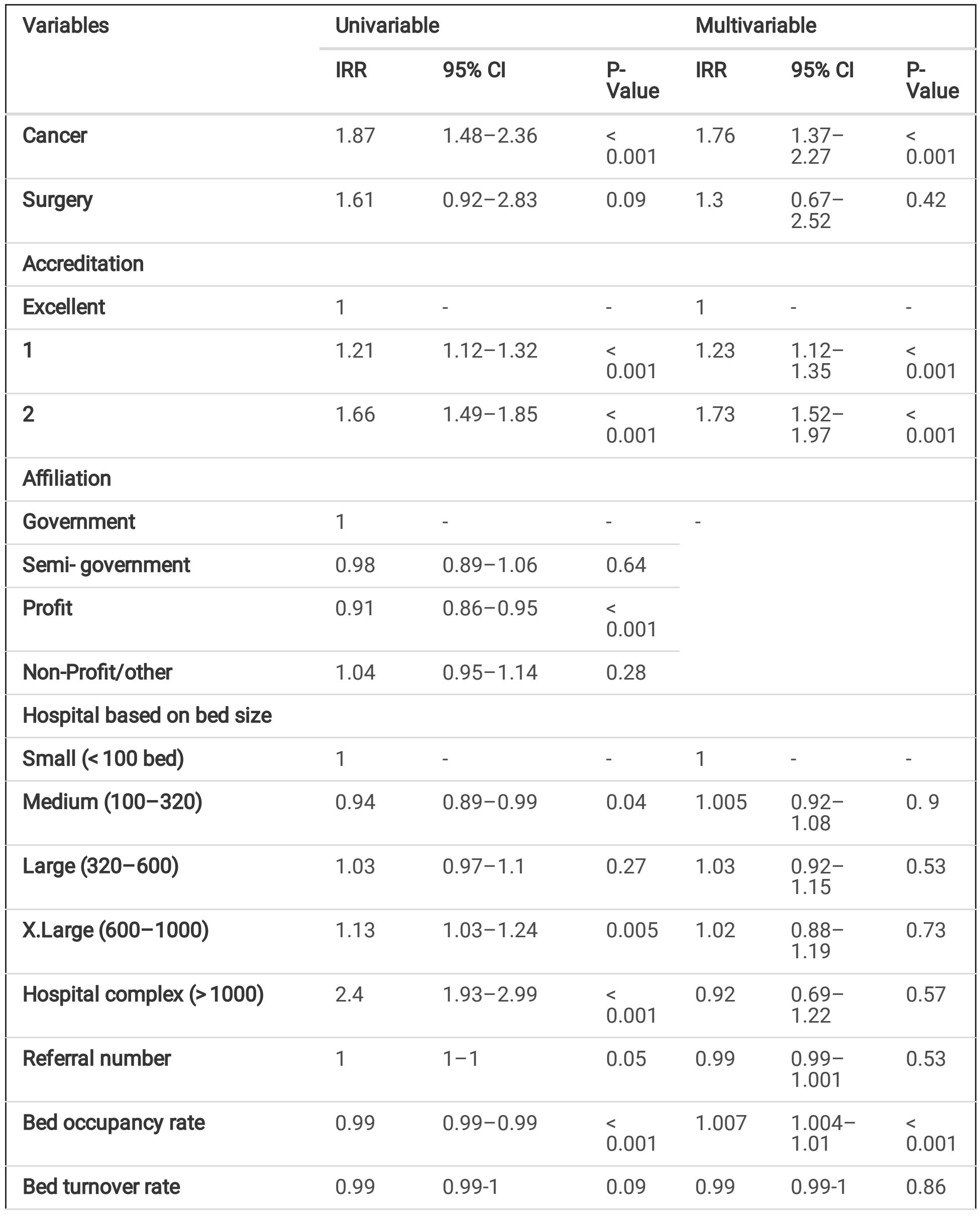

IRR = Incidence Rate Ratio; $\mathbf{C l}$ = Confidence Interval 


\begin{tabular}{|c|c|c|c|c|c|c|}
\hline \multirow[t]{2}{*}{ Variables } & \multicolumn{3}{|c|}{ Univariable } & \multicolumn{3}{|c|}{ Multivariable } \\
\hline & IRR & $95 \% \mathrm{Cl}$ & $\begin{array}{l}\text { P- } \\
\text { Value }\end{array}$ & IRR & $95 \% \mathrm{Cl}$ & $\begin{array}{l}\text { P- } \\
\text { Value }\end{array}$ \\
\hline Bed surgery turnover & 0.99 & $0.99-0.99$ & $<.001$ & 0.99 & $\begin{array}{l}0.99- \\
0.99\end{array}$ & $\dot{0}_{0.001}$ \\
\hline Personnel-to-bed ratio & 0.98 & $0.97-1.005$ & 0.18 & 1.02 & $\begin{array}{l}0.99- \\
1.05\end{array}$ & 0.12 \\
\hline Doctor-to-bed ratio & 1.001 & $0.95-1.04$ & 0.94 & - & & \\
\hline Nurse-to-bed ratio & 1.04 & $0.99-1.09$ & 0.06 & 0.97 & $\begin{array}{l}0.89- \\
1.05\end{array}$ & 0.49 \\
\hline Number of death & 1 & $0.99-1$ & 0.87 & - & & \\
\hline Number of surgery & 1.0005 & $\begin{array}{l}1.00007- \\
1.001\end{array}$ & 0.02 & 0.99 & $\begin{array}{l}0.99- \\
1.0001\end{array}$ & 0.33 \\
\hline Device-day & 1.00006 & $\begin{array}{l}1.00003- \\
1.00009\end{array}$ & $\begin{array}{l}<.001 \\
0.00\end{array}$ & 0.99 & $\begin{array}{l}0.99- \\
1.0001\end{array}$ & 0.39 \\
\hline Catheter-day & 1.00004 & $\begin{array}{l}1.00001- \\
1.00008\end{array}$ & 0.006 & 0.99 & $\begin{array}{l}0.99- \\
1.0001\end{array}$ & 0.31 \\
\hline Ventilator-day & 1.0007 & $\begin{array}{l}1.0005- \\
1.0008\end{array}$ & $<.001$ & - & & \\
\hline Mean age & 1.007 & $1.006-1.008$ & $\begin{array}{l}< \\
0.001\end{array}$ & 1.0007 & $\begin{array}{l}0.99- \\
1.001\end{array}$ & 0.16 \\
\hline $\begin{array}{l}\text { Hospitalization-infection } \\
\text { length }\end{array}$ & 1.0008 & $0.99-1.001$ & 0.86 & - & & \\
\hline Hospital LOS & 1.0001 & $0.99-1$ & 0.69 & - & & \\
\hline Male-to-patients ratio & 0.99 & $0.99-0.99$ & 0.04 & 0.99 & $\begin{array}{l}0.99- \\
1.0006\end{array}$ & 0.86 \\
\hline $\begin{array}{l}\text { Number of death (in HAls } \\
\text { patients) }\end{array}$ & 1.09 & $1.08-1.09$ & $<.001$ & 1.02 & $\begin{array}{l}1.01- \\
1.02\end{array}$ & $<.001$ \\
\hline Infection due to ventilator & 1.09 & $1.09-1.1$ & $<.001$ & 0.99 & $\begin{array}{l}0.99- \\
1.001\end{array}$ & 0.37 \\
\hline Infection due to catheter & 1.09 & $1.08-1.1$ & $\begin{array}{l}<.001 \\
0.00\end{array}$ & 0.99 & $\begin{array}{l}0.99- \\
1.0001\end{array}$ & 0.24 \\
\hline Infection due to device & 1.05 & $1.05-1.06$ & $<.001$ & 1.1 & $\begin{array}{l}1.08- \\
1.13\end{array}$ & $<.001$ \\
\hline \multicolumn{7}{|l|}{ Pabon Lasso } \\
\hline Zone I (not efficient) & 1.03 & $0.97-1.1$ & 0.25 & - & & \\
\hline
\end{tabular}




\begin{tabular}{|c|c|c|c|c|c|c|}
\hline \multirow[t]{2}{*}{ Variables } & \multicolumn{3}{|c|}{ Univariable } & \multicolumn{3}{|c|}{ Multivariable } \\
\hline & IRR & $95 \% \mathrm{Cl}$ & $\begin{array}{l}\text { P- } \\
\text { Value }\end{array}$ & IRR & $95 \% \mathrm{Cl}$ & $\begin{array}{l}\text { P- } \\
\text { Value }\end{array}$ \\
\hline Zone II & 0.96 & $0.84-1.1$ & 0.61 & & & \\
\hline Zone III (efficient) & 1 & - & - & & & \\
\hline Zone IV & 1.03 & $0.97-1.09$ & 0.21 & & & \\
\hline \multicolumn{7}{|c|}{ Average LOS indicator } \\
\hline Desirable & 1 & - & - & 1 & - & - \\
\hline Moderate & 1.09 & $1.03-1.16$ & 0.002 & 0.85 & $\begin{array}{l}0.79- \\
0.91\end{array}$ & $\begin{array}{l}< \\
0.001\end{array}$ \\
\hline Undesirable & 1.02 & $0.97-1.08$ & 0.31 & 0.79 & $\begin{array}{l}0.57- \\
1.005\end{array}$ & 0.052 \\
\hline \multicolumn{7}{|c|}{ Bed occupancy rate indicator } \\
\hline Desirable & 1 & - & - & 1 & - & - \\
\hline Moderate & 1.03 & $0.98-1.07$ & 0.17 & 1.17 & $\begin{array}{l}1.09- \\
1.25\end{array}$ & $\begin{array}{l}< \\
0.001\end{array}$ \\
\hline Undesirable & 1.03 & $0.98-1.08$ & 0.14 & 1.07 & $\begin{array}{l}0.96- \\
1.19\end{array}$ & 0.16 \\
\hline \multicolumn{7}{|c|}{ Bed turnover rate indicator } \\
\hline Desirable & 1 & - & - & \multirow[t]{3}{*}{-} & & \\
\hline Moderate & 1.005 & $0.62-1.62$ & 0.98 & & & \\
\hline Undesirable & 0.9 & $0.53-1.54$ & 0.72 & & & \\
\hline \multicolumn{7}{|c|}{ Death-to-bedridden ratio } \\
\hline Desirable & 1 & - & - & \multirow[t]{3}{*}{-} & & \\
\hline Moderate & 0.95 & $0.85-1.07$ & 0.48 & & & \\
\hline Undesirable & 1.48 & $1.4-1.56$ & $<.001$ & & & \\
\hline
\end{tabular}

Based on univariable regression, infection due to the ventilator, infection due to catheter, and the number of surgery in hospitals were associated with an increase in ICU-acquired infections incidence, but in multivariable regression, these variables were not statistically significant. As the hospital bed surgery 
turnover increases, the incidence rate of infections decreases by one percent (IRR $=0.99 ; 95 \% \mathrm{Cl}$ : $0.99-$ 0.99) (Table 3).

\section{Discussion}

The incidence of HAls depends on many factors, including medical interventions, hospital factors, and personal characteristics. In addition, it varies in hospital wards and shows that although the intensive care units have increased the recovery rate and reduced mortality, on the other hand, the length of hospital stay of these patients and the use of invasive devices and catheters have increased HAls in these wards [10].

Based on the results, the number of death (death in HAls patients), type of ICU, hospital's expertise, and bed occupancy rate indicator were associated with an increase in ICU-acquired infections incidence rate. Knowing the causes, type, and frequency of HAls can be very effective in optimal management and improving the quality of services. Therefore, organizing the nosocomial infection control committee, designing and implementing educational programs, paying attention to the basic design of the physical structure of hospital wards, creating motivational and attitudinal mechanisms in infection control are important factors that can reduce HAls [11].

Device-related infections are a leading cause of HAls, particularly in ICUs. Also, catheter-related infections are the most frequent cause of hospital-acquired bacteremia and mechanical complications and are mostly accessible to prevention if establishing standard disinfection and sterilization mechanisms and rigorous policies are implemented [12,13]. Furthermore, mechanical ventilation is a commonly used mode of support in the ICU $[11,14]$. In this study, the number of infections due to the device (catheters and ventilators) was associated with a $10 \%$ increase in ICU-acquired infections incidence rate. In addition, the most common ICU-acquired infections were VAE (38.6\%) and UTI (19.76\%), which are mostly related to the device used. Other studies show that the important infections in the ICU include UTI, pneumonia, bloodstream infections $[7,15,16]$. In Ohannessian et al.'s study, the HAls incidence rate was 14.9 per 1,000 patients-days. Furthermore, pneumonia and UTI rates were 9.7 and 6.1 per 1,000 patients-days [5]. Furthermore, in Choudhuri et al.'s study, pneumonia accounted for more than a third of HAls observed in ICUs. The duration of mechanical ventilation, duration of endotracheal intubation, duration of urinary catheterization, and ICU length of stay were significantly related to ICU-acquired infections [17].

Present findings imply that device-related infections are associated with increased complications and costs. Therefore, the specific preventive strategies of device-related infections, establishing a system of reporting and follow-up, healthcare workers' education and training about the use of invasive devices are necessary to reduce the ICU-acquired infections.

However, our study had some limitations. One, this study was a retrospective study, so there is a possibility of some biases. Second, the impact of pathogens, antimicrobial resistance, and other factors on ICU-acquired infections incidence rate was not considered in our study and may limit our interpretation. But, this study was a multicenter study and conducted using registered data, so it can be 
claimed that the results are generalizable. In addition, this study was the first large sample size, comprehensive and national study that was conducted the investigating factors associated with ICUacquired infections incidence and will be better clarify the factors affecting the occurrence of infections.

\section{Conclusions}

Based on the results, internal ICU had the largest increase in ICU-acquired infections incidence compared to the NICU and the most common ICU-acquired infections were VAE and UTI. The occurrence of HAls in medical centers is inevitable and its control is one of the most important health goals of medical centers. Therefore due to the high sensitivity of intensive care units, full hygiene should be taught to the medical staff, especially the ICU wards. Ventilators and catheters should be used in special circumstances and minimum duration. Regular hand washing, the use of antimicrobial gels, and the use of disposable gloves and masks in the face of patients are very reasonable and necessary.

\section{Abbreviations}

$A V A B=$ Hospital statistics and information system

CAUTI= Catheter-related urinary tract infection

CLABSI= Central line-associated blood stream infections / septicemia

HAls= Hospital-acquired infections

ICU-Als= ICU-acquired infections

ICUs= Intensive care units

INIS= Iranian Nosocomial Infections Surveillance

$\mathrm{IQR}=$ Interquartile range

LOCF $=$ Last observation carried forward

LOS= Length of stay

MOHME $=$ Ministry of Health and Medical Education

$\mathrm{NICU}=$ Neonatal Intensive care units

PICU= Pediatric Intensive care units

SSI= Surgical Site Infection

VAE/VAP = Ventilator-associated events / respiratory infections / pneumonia 


\section{Declarations}

\section{Ethic's approvaland consent to participate}

All procedures performed in the study were in accordance with the ethical standards of the School of Public Health \& Neuroscience Research Center- Shahid Beheshti University of Medical Sciences research committee (approval ID = IR.SBMU.PHNS.REC.1398.167) and with the 1964 Helsinki declaration and its later amendments or comparable ethical standards.

\section{Consent to publish}

Not applicable. The manuscript does not contain patient identifiable data.

\section{Availability of data and materials}

The datasets used and/or analysed during the current study are available from the corresponding author on reasonable request.

\section{Competing interests}

The authors declare that they have no competing interests.

\section{Funding}

This study was supported by Shahid Beheshti University of Medical Sciences grant number 20700. The funding agency did not play any role in the planning, conduct, and reporting or in the decision to submit the paper for publication.

\section{Authors' Contributions}

N. I: Contribution to study concept and design, acquisition, analysis and interpretation of data, drafting of manuscript

B. E: Contribution to study concept and design, acquisition, analysis and interpretation of data

Y. M: Contribution to analysis and interpretation of data

K. E: Contribution to drafting of manuscript

SS. HN: Contribution to study concept and design, acquisition, analysis and interpretation of data, drafting of manuscript

All authors have read and approved the manuscript

\section{Acknowledgments}


This paper was extracted from an epidemiology graduate thesis. We would like to express our thanks to all the staff of Iranian nosocomial infections surveillance hospital and statistics and information system department of the ministry of health, Iran as well as to all individuals helping us in completing this research project.

\section{References}

1. World Health.Organization. Report on the burden of endemic health care-associated infection worldwide. 2011.

2. Chastre J, Luyt C-E, Wolff M, editors. Serious Infections in the ICU: Evolving Concepts in Management and Prevention. Seminars in respiratory and critical care medicine; 2019: Thieme Medical Publishers.

3. Magill SS, Edwards JR, Bamberg W, Beldavs ZG, Dumyati G, Kainer MA, et al. Multistate pointprevalence survey of health care-associated infections. New England Journal of Medicine. 2014;370(13):1198-208.

4. De Angelis G, Murthy A, Beyersmann J, Harbarth S. Estimating the impact of healthcare-associated infections on length of stay and costs. Clinical microbiology and infection. 2010;16(12):1729-35.

5. Ohannessian R, Gustin M-P, Bénet T, Gerbier-Colomban S, Girard R, Argaud L, et al. Estimation of extra length of stay attributable to hospital-acquired infections in adult ICUs using a time-dependent multistate model. Critical care medicine. 2018;46(7):1093-8.

6. Edwardson S, Cairns C. Nosocomial infections in the ICU. Anaesthesia \& Intensive Care Medicine. 2019;20(1):14-8.

7. Inan D, Saba R, Yalcin AN, Yilmaz M, Ongut G, Ramazanoglu A, et al. Device-associated nosocomial infection rates in Turkish medical-surgical intensive care units. Infection Control \& Hospital Epidemiology. 2006;27(4):343-8.

8. Ling ML, Apisarnthanarak A, Madriaga G. The Burden of Healthcare-Associated Infections in Southeast Asia: A Systematic Literature Review and Meta-analysis. Clinical infectious diseases : an official publication of the Infectious Diseases Society of America. 2015;60(11):1690-9.

9. Despotovic A, Milosevic B, Milosevic I, Mitrovic N, Cirkovic A, Jovanovic S, et al. Hospital-acquired infections in the adult intensive care unit-Epidemiology, antimicrobial resistance patterns, and risk factors for acquisition and mortality. American journal of infection control. 2020.

10. Timsit J-F, Rupp M, Bouza E, Chopra V, Kärpänen T, Laupland K, et al. A state of the art review on optimal practices to prevent, recognize, and manage complications associated with intravascular devices in the critically ill. Intensive Care Medicine. 2018;44(6):742-59.

11. Liang J, Li Z, Dong H, Xu C. Prognostic factors associated with mortality in mechanically ventilated patients in the intensive care unit: a single-center, retrospective cohort study of 905 patients. Medicine. 2019;98(42).

12. Buetti N, Timsit J-F, editors. Management and prevention of central venous catheter-related infections in the ICU. Seminars in respiratory and critical care medicine; 2019: Thieme Medical 


\section{Publishers.}

13. van der Kooi T, Sax H, Pittet D, van Dissel J, van Benthem B, Walder B, et al. Prevention of hospital infections by intervention and training (PROHIBIT): results of a pan-European cluster-randomized multicentre study to reduce central venous catheter-related bloodstream infections. Intensive care medicine. 2018;44(1):48-60.

14. Fialkow L, Farenzena M, Wawrzeniak IC, Brauner JS, Vieira SRR, Vigo A, et al. Mechanical ventilation in patients in the intensive care unit of a general university hospital in southern Brazil: an epidemiological study. Clinics. 2016;71(3):144-51.

15. Richards M, Thursky K, Buising K, editors. Epidemiology, prevalence, and sites of infections in intensive care units. Seminars in respiratory and critical care medicine; 2003: Copyright@ 2002 by Thieme Medical Publishers, Inc., 333 Seventh Avenue, New ....

16. Ramritu P, Halton K, Cook D, Whitby M, Graves N. Catheter-related bloodstream infections in intensive care units: a systematic review with meta-analysis. Journal of advanced nursing. 2008;62(1):3-21.

17. Choudhuri AH, Chakravarty M, Uppal R. Epidemiology and characteristics of nosocomial infections in critically ill patients in a tertiary care intensive care unit of Northern India. Saudi journal of anaesthesia. 2017;11(4):402.

\section{Figures}

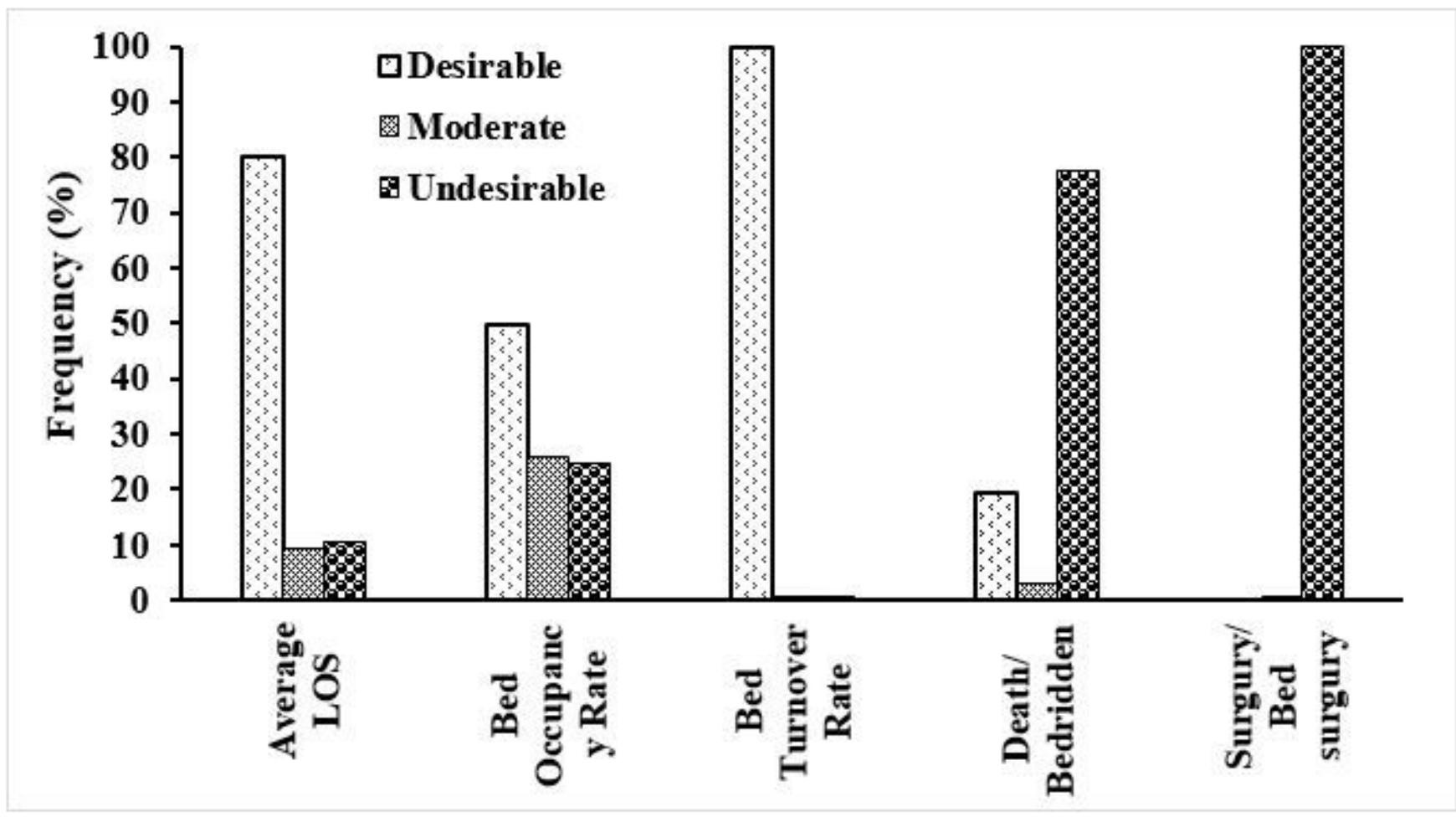

Figure 1 
The frequency of hospital indicators in ICU of Iran hospitals-2018

Page 18/18 